\title{
STRESSORS IN TEACHER'S WORK
}

\author{
Lijana Navickienè ${ }^{1}$, Eglè Stasiūnaitienè ${ }^{2}$, Ilona Kupčikienė $\dot{1}^{1}$, Donatas Misiūnas ${ }^{1}$ \\ ${ }^{1}$ Kaunas College/University of Applied Sciences, ${ }^{2}$ Vytautas Magnus University, Lithuania
}

Key words: stress, stressors, teacher stress, stressors in teacher work.

\begin{abstract}
Summary
Teachers are among the professions which face the highest level of work-related stress. High level of stress has a negative impact on the teacher's physical and emotional health, leads to exhaustion, burnout, dissatisfaction with work, and high turnover rates. It is therefore important to reveal the main sources and risks of stress in the teacher's work. Psychosocial risks are related to the negative psychological, physical and social consequences resulting from inadequate work organization and management at the workplace: too high work requirements and / or short deadlines for fulfilling tasks; conflicting requirements and unclear employee roles; poor use of staff skills and insufficient employees involvement in decisionmaking on their work; scarse management and coworkers support and poor relationships with colleagues, students and their parents.

A quantitative study conducted in five countries revealed that most teachers experience a high level of stress in their professional activity. Many stressors in professional activity relate to the uncertainty and excessive workload of teachers' functions and roles. The most common organizational factors that cause stress include working conditions, low salary, noisy environment, number of students in the classroom, and external factors such as educational reforms and social status in society. The least stressors identified in the teachers' professional activity relate to relationships and support in the work environment. The study was conducted in the framework of the international project "Preventing Stress in the Teaching Profession-Stress Free Teachers", No. 20163715 / 001-001.
\end{abstract}

\section{Introduction}

Stress refers to the circumstances when a person can not or does not have the measures to respond appropriately to environmental stimuli, or can react only by harming him/ herself, for example. constant weariness, tension, troubles, nervous exhaustion and loss of self-esteem [13]. It is a negative situation or a harmful event in a particular environment that affects humans and causes negative physiological and psychological consequences. This situation or event acts as stressors that affect coercive continued state of mental and physiological tension, the entirety of body's protective reactions $[7,8]$.

Stressors are events or circumstances which create the feeling that physical or psychological demands are approaching the limits of person's abilities to cope with them $[4,16]$. In research performed by Gostautas et al. (2002), Karkockienè (2011), McGregor et al. (2008), Poon (2010), the relation beween stress and changes in physical health is fixed $[6,9,10,15]$. The research works of Chen H. Et al. (2009), Poon (2010), Prilleltensky (2016) and other authors identify the relationship between the consequences of stress and the mental health of the individual, highlight the tendency that increasing physical and psychological strain leads to stress formation and worsening psychological well-being $[3,4,15,16]$. It has been identified that stress is related to lifestyle changes, alcohol, tobacco or drug use, sleep disorder, lower physical activity, which in turn affects physical and mental health $[7,9,14]$. Azaraviciene and others (2008) note that typical diseases caused by various stressors include hypertonic disease, gastric or duodenal ulcer, migraine, myocardial infarction, some immune, allergic diseases, and mental disorders [1].

In the course of rapid social changes and various educational reforms, as the requirements for the quality of the education process and teachers 'responsibilities increase, teachers' professional activity is at the heart of the process of continuous change. The influence of stress on the teacher's professional activity was studied by Mérida-López S. et. Al. (2017), Prilleltensky et al. (2016), Phillips et al. (2008), Poon et al. (2010).

The pressure faced in teacher's everyday professional activity, the attitude of society towards teacher's work and 
professional status are referred to as a threatening and aggressive environment that causes a tension and helplessness. All of this has a particularly strong impact on the teacher's physical and mental health and efficiency of work. Stressors appearing in the teacher's professional activities can be divided into four groups: the work content, working conditions, work organization and social relations at work.

The manifestation of stress symptoms is most commonly observed in emotional, thinking, physiological, behavioural reactions, also cognitive and motivational processes $[11,13]$.

The aim of this article is to identify teachers' stress level and the stressors that are the most common in their daily professional activity. To reach this aim the scientific literature on the topic has been analysed and the survey was performed.

\section{Research methods}

For the study a quantitative research method was used. The survey was carried out in spring, 2018. Data for the study was obtained from a comprehensive online survey of teachers $(n=308)$ across the following countries: Portugal, Slovenia, Bosnia and Herzegovina, Lithuania and Turkey. For this purpose online questionnaires for teachers were prepared and circulated via e-mails to schools in the mentioned countries. Participation in survey was based on volunteering principle. The anonymity of survey participants was ensured.

Data were processed using an SPSS program (Statistical Package for Social Sciences, version 21.0).

Logic of questionnaires construction. The questionnaires include questions related to 2 main areas:

1. Socio-demographic characteristics of respondents (teachers age, gender, work experience, type of school in which respondents work).

2. Sources of teacher stress/stressors. Stressors listed in questionnaires were identified from literature studies on stress and relate to five main areas (Table 1).

Ethical research principles. The survey was conducted in accordance with the basic ethical principles. From potential research participants the informed concept was obtained: scope and objectives of the survey, the research methods being used, and possible outcomes of the research as well as future follow-up were explained (in face-to face or/and written form) to research target group members. Participation in survey was based on volunteering principle, teachers took part in study without having been coerced and deceived. The survey was anonymous, ensuring the confidentiality of the participants. These

Table 1. Areas of stressors listed in questionnaires for teachers

\begin{tabular}{|c|c|}
\hline Area of stressors & Description of stressors in questionnaire \\
\hline \multirow{9}{*}{$\begin{array}{l}\text { Work content } \\
\text { (requirements for } \\
\text { teacher compe- } \\
\text { tencies, functions, } \\
\text { tasks, responsi- } \\
\text { bilities) }\end{array}$} & Teacher attestation, certification \\
\hline & $\begin{array}{l}\text { Changing requirements for the role and competencies of the } \\
\text { teacher (ex. integration of IT into the teaching process, indivi- } \\
\text { dualization of education, inclusive education) }\end{array}$ \\
\hline & Unclear duties and responsibilities \\
\hline & Filling in documents, abundance of reports and paperwork \\
\hline & Achieving the goals of the curriculum \\
\hline & Pressure linked to preparing pupils for exams \\
\hline & Requirements for the teacher at school \\
\hline & Inadequate teacher's work assessment at school \\
\hline & Upgrading qualification \\
\hline \multirow{5}{*}{$\begin{array}{l}\text { Work conditions } \\
\text { (wage, work envi- } \\
\text { ronment, physical } \\
\text { conditions) }\end{array}$} & Low salary \\
\hline & Noisy environment \\
\hline & Permanent changes at work \\
\hline & Lack of teaching/learning measures and devices \\
\hline & Many pupils in class \\
\hline \multirow{5}{*}{$\begin{array}{l}\text { Work organiza- } \\
\text { tion (workload, } \\
\text { time manage- } \\
\text { ment, control) }\end{array}$} & The need to work overtime \\
\hline & Urgent execution of unplanned additional tasks \\
\hline & Abundance of work roles \\
\hline & Work check and control \\
\hline & Lack of time to accomplish all the tasks \\
\hline \multirow{10}{*}{$\begin{array}{l}\text { Relationships } \\
\text { (encouragement, } \\
\text { conflicts, support, } \\
\text { autonomy) }\end{array}$} & Authoritarian behavior of management/administration staff \\
\hline & Problematic relationships with management/administration staff \\
\hline & Disputes with pupils \\
\hline & Problematic relationships with pupils' parents \\
\hline & Pupils' mischievous, disrespectful behavior \\
\hline & Public critique by colleagues \\
\hline & Non-constructive feedback on work done \\
\hline & Gossips among colleagues \\
\hline & Competitive relationships with colleagues \\
\hline & Lack of communication and cooperation at work \\
\hline \multirow{5}{*}{$\begin{array}{l}\text { Other (external) } \\
\text { stressors } \\
\text { (education policy, } \\
\text { professional sta- } \\
\text { tus, demographic } \\
\text { situation, personal } \\
\text { situation) }\end{array}$} & Bad social status of teacher in the society \\
\hline & Reforms of education system \\
\hline & $\begin{array}{l}\text { Declining demographic indicators. The lack of school-age } \\
\text { children }\end{array}$ \\
\hline & $\begin{array}{l}\text { Personal characteristics (lack of self-confidence, sensitivity, } \\
\text { intolerance to criticism, etc.) }\end{array}$ \\
\hline & The isolation of the teaching profession \\
\hline
\end{tabular}


principles helped to ensure the reliability and objectivity of the collected data.

\section{Results}

308 teachers from 5 partner countries (Slovenia, Portugal, Bosnia and Hercegovina, Turkey and Lithuania) participated in the survey. Most of teachers were women (86\%). 14\% of participants were men. This supports the fact that teaching is strongly feminised profession in many countries. For example, Eurydice report found that in secondary education, teaching is a job largely exercised by women: at EU level, less than a third of the teaching force $(32.2 \%)$ are men, while in some countries, Lithuania being among them, as few as one in five teachers are men [17].

The statistics show that average age of teachers in Europe is $43-47$ years [12]. Most probably this data has led to the fact that majority of survey participants $65 \%$ of teachers) belongs to the middle-aged people group (36-55 y, Figure 1). Being this age teachers have considerable teaching experience - more than $70 \%$ of teachers have been teaching for more than 10 years (Figure 2).

Most of the survey participants are employed at primary and secondary schools while $8 \%$ of teachers are from VET schools (Figure 3).

Stressors in teachers' work. Questionnaires data have indicated that $61 \%$ of teachers reported their work environ-

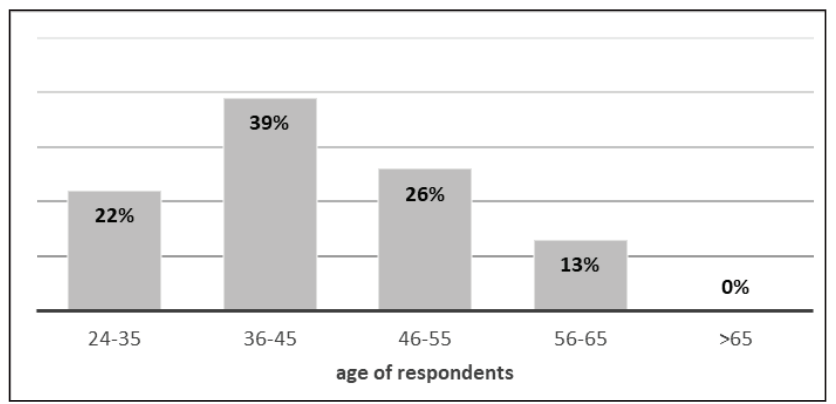

Figure 1. Age of survey participants

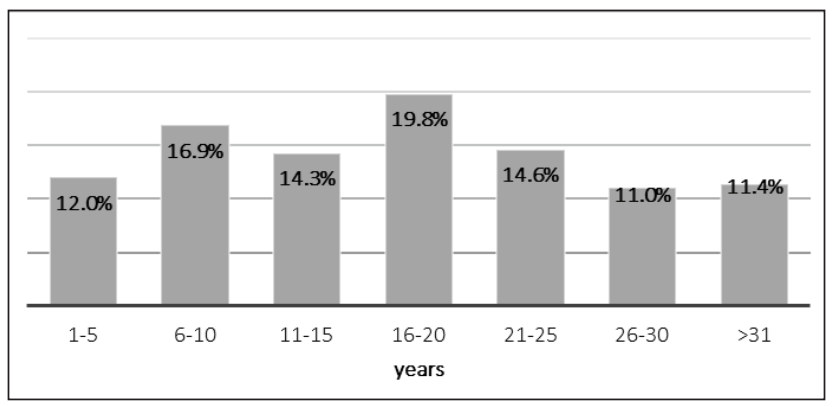

Figure 2. Work experience of survey participants ment as very stressful or stressful (Figure 4). Survey results show female teachers experience higher level of stress than man teachers.

No significant difference in perceived stress level is found between teachers with different years of teaching experience. Number of pupils in class or education institution in which teachers work also do not have relevant impact on teachers' stress level. However, teachers in Turkey reported to feel significantly lower stress level than those in other partner (Figure 5).

The frequency of various sources of work stress reported by the teachers is shown in Figures 6-10. Approximately 1/3 of teachers reported that filling in documents, abundance of reports and paperwork, low salary, the need to work overtime, abundance of work roles, many pupils in class and noisy environment cause their constant stress every day.

In addition to the mentioned factors, pressure linked to preparing pupils for exams, achieving the goals of the curriculum, lack of time to accomplish all the tasks, inadequate teacher's work assessment at school, changing requirements for the teacher's roles and competencies are the main stressors that most teachers $(70-80 \%)$ reported as being faced constantly, very often or often. Also the most frequent stressors in teachers' work include the isolation of teaching profession, bad social status of teacher in the society, unclear duties and responsibilities. Approximately

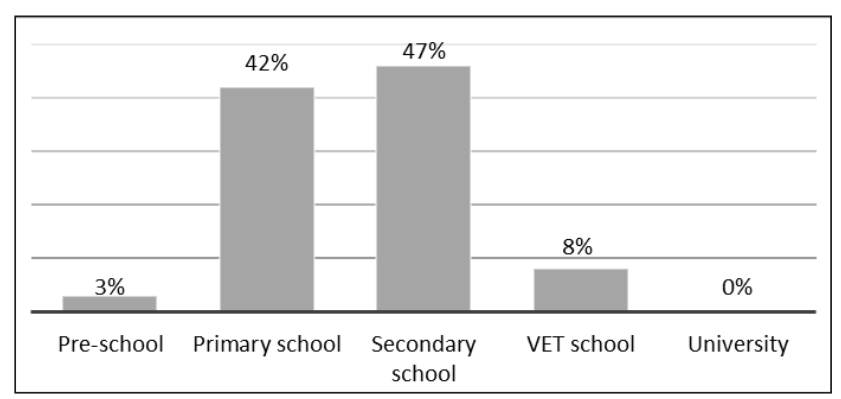

Figure 3. Type of education institution in which survey participants work

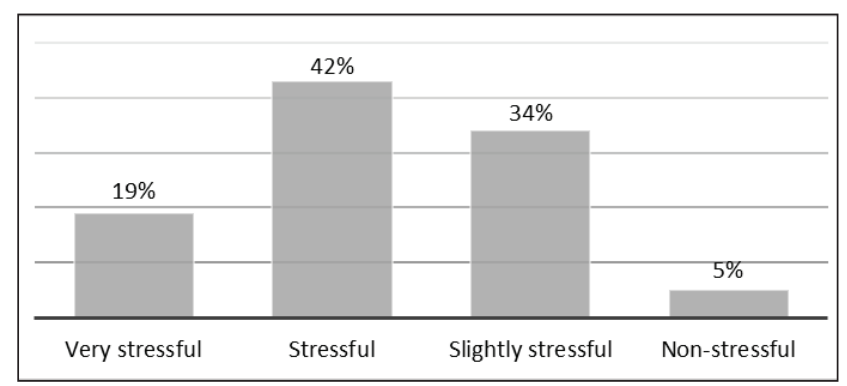

Figure 4. Teachers' work - stress level 
half of teachers feel stress rather often because of disputes with pupils and their parents, pupils' disrespectful behavior, work check and control, lack of communication at work. Personal characteristics, competitive relationships with colleagues, gossips among colleagues and some other factors related to social relationships are among the less frequent stressors in teachers' work.

The daily filling in documents as a very frequent stressor is mentioned by respondents from Portugal $(55 \%)$ and Slovenia (37\%). The preparation of students for exams and the attainment of the objectives of the curriculum as significant stressors are usually indicated in the responses of Portuguese respondents ( $42 \%$ and $40 \%$ ). Respondents who participated in the survey reported the inadequate teacher's work assessment as a frequent stressor as follows: Lithuanian and Slovenian respondents $14 \%$, Portugal $-20 \%$, Turkish $-23 \%$, Bosnian and Herzegovans $-21 \%$. Teachers' certification as the least stressful factor was indicated by respondents from all countries.

Low salary is referred to as a relevant stressor among respondents from Lithuania and Portugal ( $45 \%$ and $43 \%$ ). One third of the respondents from Bosnia and Herzegovina, Turkey and Portugal identified a large number of learners in the classroom as a significant stressor in teaching work. The noisy environment as an important stressor is indicated by respondents from Lithuania and Slovenia (37\% and $31 \%$ respectively). Permanent changes at work are the most significant stressor for Portuguese respondents $(26 \%)$.

More than half (58\%) of Portuguese respondents point out the need to work overtime as a significant stressor in work organization area. The execution of unplanned tasks as a significant stressor is reported by Portuguese and Turkish respondents (38\% and 33\% respectively). Work control has been reported as the least stressful factor in the responses of all respondents. The most significant stressors in the area of work organization emerged to be overtime, abundance of work roles $(21 \%)$ and lack of time to accomplish all the tasks (19\%).

Pupils' disrespectful behaviour as an important stressor is pointed out by $1 / 3$ of the Turkish respondents. The authoritarian behaviour of the administration staff and the non-constructive feedback on work done as frequent stressors, are common in responses by Turkish respondents $(22 \%$ and

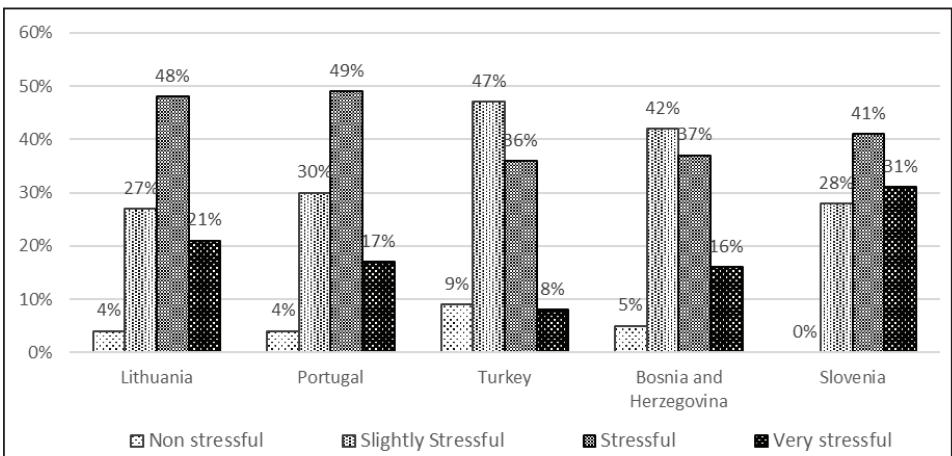

Figure 5. Teachers' work - stress level by countries

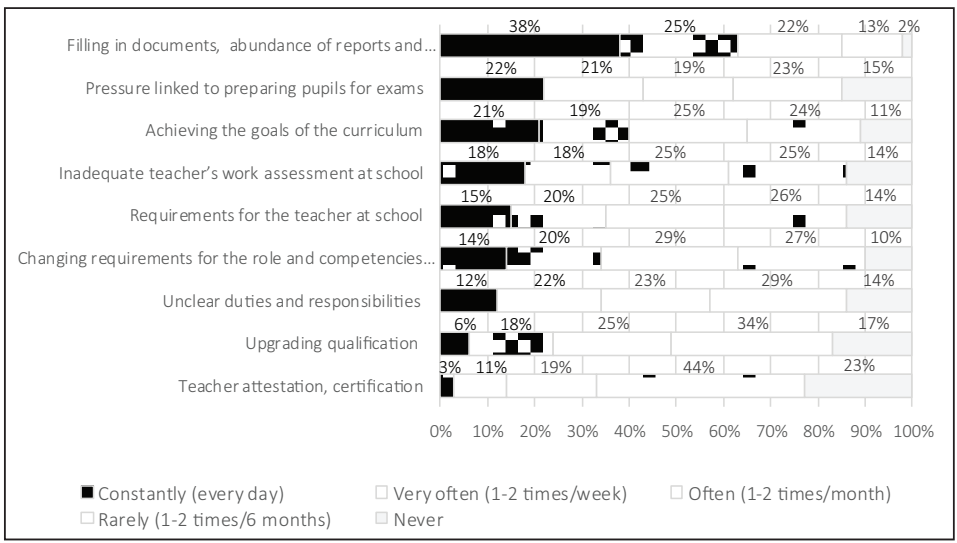

Figure 6. Frequency of stressors of work content area in teachers' work

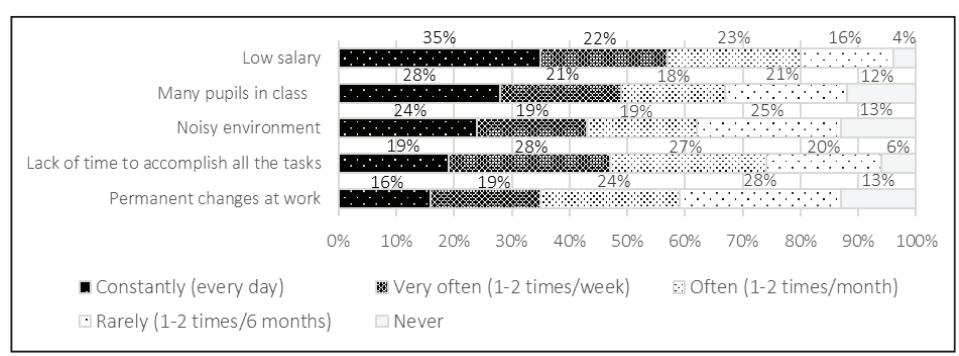

Figure 7. Frequency of stressors of work condition area in teachers' work

$25 \%$ ). Problematic relationship with the administration as a significant stressor is reported by Turkish (22\%) and Slovenian respondents (27\%). While assessing this group of stressors disrespectful students' behaviour and authoritarian style of administration (12\% and $12 \%$, respectively) were most often mentioned by Lithuanian respondents.

Reforms in the education system are referred to as the most significant stressor among the responses of respondents in all countries, however most often this stressor was mentioned by respondents from Portugal (29\%), Turkey (20\%), Bosnia and Herzegovina (32\%) and Lithuania (17\%). More than one third of Turkish respondents identify the isolation of teachers' profession as an important stressor in the 


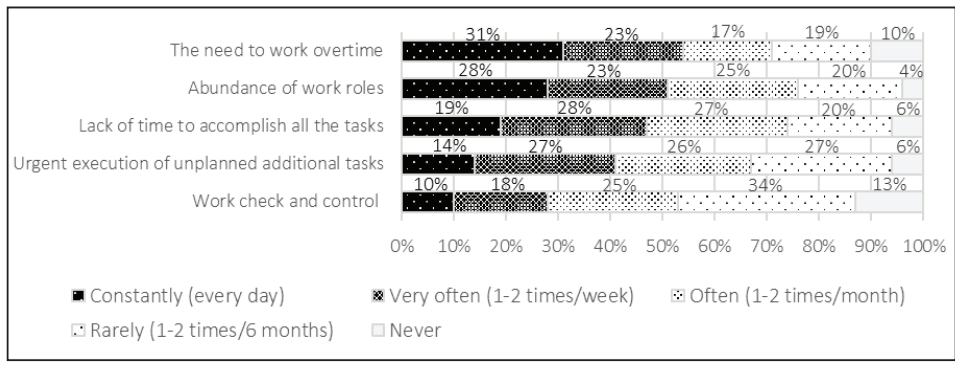

Figure 8. Frequency of stressors of work organization area in teachers' work

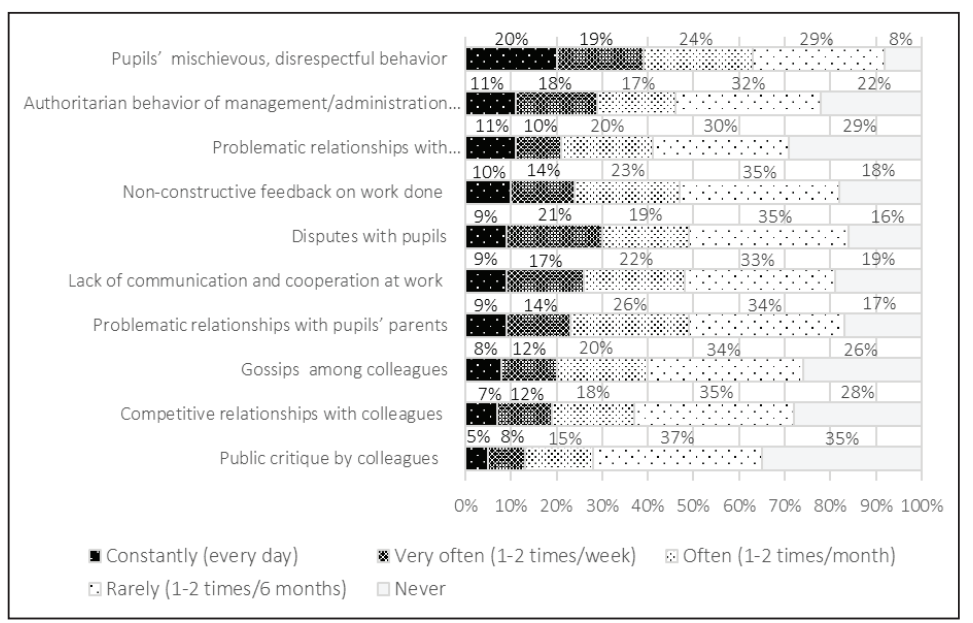

Figure 9. Frequency of stressors of relationship area in teachers' work

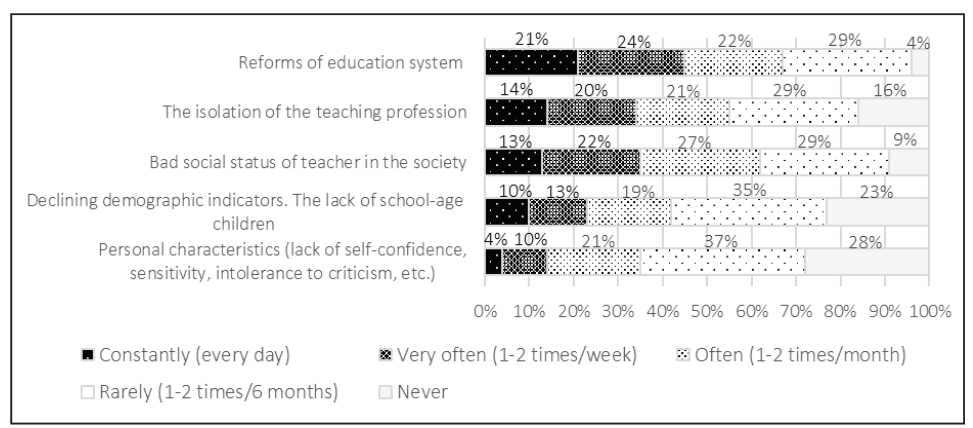

Figure 10. Frequency of other stressors in teachers' work

teacher work. The replies of the Lithuanian respondents regarding frequency of this group of stressors were as follows: the isolation of teaching profession as an frequent stressor in teacher work was reported by $4 \%$ of Lithuanian survey participants, the low status of the teacher's profession - by $6 \%$ of Lithuanian respondents. Demographic changes and the decline of school-age children causes stress to $10 \%$ of survey participants from Lithuania.

\section{Conclusions}

1. Stress is an individual forced mental and physiological state of a person's tension that occurs as a reaction to the effects of negative factors that can not be avoided subjectively if the person is unable to control the situation. This condition is caused by harmful environmental and internal factors - stressors. In teachers' professional activity stressors fall into 4 groups: the work content, working conditions, work organization, and relationships.

2. Majority of teachers face high level of stress in their work. From the results obtained through the survey it has become evident that some factors are more prone to cause stress amongst teachers than others. The most frequent stressors in teachers " work are linked to their functions and role overload, workload. This highlights how the amount of work together with the multiplications of areas of responsibility and roles constitute the main stressors for teachers.

3. Work conditions - low salary, noisy environment, number of pupils in class as well as external factors, like education reforms, social status in society are among the most frequent stressors as well. The stressors related to relationships and support are found to be less frequent in teachers" work.

\section{References}

1. Azaravičienė A., Dulskienė V., Malinauskienė V. Gyvenimo būdo bei darbo aplinkos įtaka miokardo infarkto rizikai 35-46 m. moterims Kaune. Prieiga per internetą: http://su.lt/old.su/bylos/mokslo_leidiniai/llyciu_studijos/2008_5/azareviciene.pdf. [žiūrèta: 2018-09-10].

2. Bandzienè A. Kompleksinis streso darbe valdymas. Daktaro disertacija. ISM Vadybos ir ekonomikos universitetas, 2009.

3. Mahan PL, Mahan MP, Park NJ, Shelton C, Brown KC, Weaver MT. Work environment stressors, social support, anxiety, and depression among secondary school teachers. Workplace Health and Safety 2010; 58,5:197-205 Prieiga per internetą: https://journals.sagepub.com/doi/ abs/10.1177/2165079910058005044

4. Chen H, Wong Y, Ran MS, Gilson Ch. Stress among Shanghai university students. The need for social work support. Journal of Social Work 2009; 9:323344. Prieiga per internetą: http://jsw.sagepub.com/ content/9/3/323.full.pdf+html. [žiūrèta: 2018-1110].

5. Bilehoj H. Report on the ETUCE survey on teachers' work related stress. European Trade Union Committee for Education 2007. Prieiga per internetą: https:// 
www.csee-etuce.org [žiūrèta: 2018-11-10].

6. Goštautas A., Gustainienė L., Perminas A., Šinkariova L., Ausmanienė N., Statkevičienė A. Kraujospūdžio kitimai taikant ankstyvosios psichologines reabilitacijos priemones stacionaro sąlygomis. Medicinos teorija ir praktika, 2002;31(3):188-192.

7. Herman K, Hickmon-Rosa J, Reinke, W. Empirically derived profiles of teacher stress, burnout, self-efficacy and coping and associated student outcomes. Journal Of Positive Behavior Interventions [serial online] 2018; 20(2):90-100.

https://doi.org/10.1177/1098300717732066

8. Holman EA, Silver RC, Mogle JA, Scott SB. Adversity, time, and well-being: a longitudinal analysis of time perspective in adulthood. Psychology and Aging 2016;31(6):640-651. Prieiga per internetą: http://dx.doi.org/10.1037/pag0000115 [žiūrèta 2018-09-15].

https://doi.org/10.1037/pag0000115

9. Karkockienė D. Medicinos ir sveikatos mokslų studentų patiriamo streso ypatumai ir jo ittaka miego kokybei. Visuomenès sveikata, 2011; 2(53):83-92.

10. McGregor BA, Antoni MH, Ceballos R, Blomberg BB. Short communication: very low CD19+ B-lymphocyte percentage is associated with high levels of academic stress among healthy graduate students. Stress and Health 2008;24:413-418. Prieiga per internetą: http://web.ebscohost.com/ehost/ pdf?vid $=22 \&$ hid $=105 \&$ sid $=52 \mathrm{c} 0 \mathrm{e} 842-56 \mathrm{dc}-40 \mathrm{e} 2-\mathrm{a} 0 \mathrm{a} 3-$ 37c4d7cdac43\%40sessionmgr114. [žiūrèta: 2018-09-25].

11. Mérida-López S, Extremera N, Rey L. Emotion-regulation ability, role stress and teachers' mental health. Occupational Medicine 2017;67-7:540-545. Prieiga per internetą: https:// doi.org/10.1093/occmed/kqx125. [žiūrèta: 2018-09-27]. https://doi.org/10.1093/occmed/kqx125

12. Distribution of teachers for age and gender. Organisation for Economic Co-operation and Development. Prieiga per internetą: https://stats.oecd.org/Index.aspx. [žiūrèta: 2018-01-25].

13. Phillips SJ, Sen D, McNamee R. Risk factors for work-related stress and health in head teachers. Occupational Medicine 2008;58:584-586. Prieiga per internetą: http://citeseerx.ist.psu. edu/viewdoc/ [žiūrèta: 2018-03-25].

https://doi.org/10.1093/occmed/kqn112

14. Pikūnas J., PalujanskienėA. Stresas. Atpažinimas ir įveikimas, 2005. Pasaulio lietuvių kultūros, mokslo ir švietimo centras.

15. Poon WC, Yap SF, Ong TP. Academic stress and health outcomes: evidence from undergraduate students. IATED digital library. ICERI Proceedings 2010; 6890-6901. Prieiga per internetą: https://library.iated.org/publications/ICERI2010 [žiūrèta: 2018-11-12].
16. Prilleltensky I, Neff M, Bessell A. Teacher stress: what it IS, why It's important, how it can be alleviated. Theory into Practice 2016; 55:104-111. Prieiga per internetą: https://www. tandfonline.com/doi/abs [žiūrèta: 2018-09-12].

https://doi.org/10.1080/00405841.2016.1148986

17. Strenghening teaching in Europe 2015. Prieiga per internetą: http://ec.europa.eu/assets/eac/education/library/ policy/teaching-profession-practices_en.pdf. [žiūrèta: 2018-09-25].

\section{STRESORIAI MOKYTOJO DARBE}

\section{L.Navickienė, E.Stasiūnaitienė, I.Kupčikienė, D.Misiūnas}

Raktažodžiai: stresas, stresoriai, mokytojo stresas, stresoriai mokytojo darbe.

\section{Santrauka}

Mokytojas yra viena iš profesijų, kurioje patiriamas aukščiausias streso lygis. Aukštas streso lygis turi neigiamą poveikị mokytojo fizinei ir emocinei sveikatai, sąlygoja išsekimą, ,perdegimą“", nepasitenkinimą dirbamu darbu, didelę šios profesijos žmonių kaitą. Dèl to svarbu atskleisti svarbiausius mokytojo darbe patiriamo streso šaltinius ir rizikas. Psichosocialinè rizika susijusi su neigiamomis psichologinèmis, fizinėmis ir socialinėmis pasekmèmis, atsirandančiomis dèl netinkamo darbo organizavimo ir vadybos darbo vietoje: per dideli darbo reikalavimai ir (arba) per trumpi terminai užduotims įvykdyti; prieštaringi reikalavimai ir neaiškūs darbuotojų vaidmenys; nepakankamas darbuotojų sugebejjimų panaudojimas ir nepakankamas darbuotojų dalyvavimas priimant su jų darbu susijusius sprendimus; per menka vadovų bei kolegų pagalba ir prasti tarpusavio santykiai su kolegomis, mokiniais ir jų tèvais.

Kiekybinis tyrimas, atliktas 5 šalyse, atskleidè, kad dauguma mokytojų patiria aukštą streso lygị savo profesineje veikloje. Daugelis profesinèje aplinkoje veikiančių stresorių yra susiję su mokytojų funkcijų ir vaidmenų neapibrèžtumu bei per dideliu darbo krūviu. Labiausiai paplitę stresą sukeliantys organizaciniai veiksniai yra darbo sąlygos, mažas atlyginimas, triukšminga aplinka, mokinių skaičius klasejje, taip pat išoriniai veiksniai, tokie kaip švietimo reformos, socialinė padėtis visuomenèje. Mažiausiai mokytojų profesinèje veikloje identifikuota stresorių, susijusių su santykiais ir parama darbo aplinkoje.

Tyrimas atliktas igyvendinant tarptautinị projektą "Preventing Stress in the Teaching Profession-Stress Free Teachers", Nr. 2016-3715/001-001.

Adresas susirašinèti: lijana.navickiene@go.kauko.lt

Gauta 2018-11-27 